\title{
Pengaruh Sapa Orangtua Remaja terhadap Pengetahuan, Sikap dan Perilaku Orangtua tentang Pendidikan Kesehatan Reproduksi
}

\author{
Dyah Widiyastuti ${ }^{1}$, Lia Nurcahyani ${ }^{2}$ \\ ${ }^{1,2}$ Program Studi D.III Kebidanan Cirebon, Poltekkes Kemenkes Tasikmalaya \\ Korespondensi: widiyastuti_dyah@yahoo.co.id
}

Submisi: 29 April 2019; Revisi:13 Desember 2019; Penerimaan: 23 Desember 2019

\begin{abstract}
Background: Premarital sex is a problem that is prone to adolescence. One reason is the lack of knowledge about reproductive health. Reproductive health education is very important, but the majority of parents have less knowledge and negative perceptions of adolescent reproductive health.

Objective: To analyze differences in knowledge, attitudes and behavior of parents before and after being given an intervention Greet Adolescent Parents.

Method: The design of the quasi experimental non randomized pre test and post test one group design. The subjects of this study were 35 parents of the Pamitran Elementary School in Cirebon City with inclusion and exclusion criteria. The research instruments included questionnaires and modules for greeting parents of adolescents. Data analysis using wilcoxon and paired t-test.

Results and Discussion: There were significant differences in the knowledge of parents 'attitudes and behaviors before and after the intervention ( $p$ value $0.003 ; 0.000$ and 0.013 )

Conclusion: Greeting parents of parents can improve parents' knowledge, attitudes and behavior regarding adolescent reproductive health.
\end{abstract}

Keywords: Greet teen parents; knowledge; attitude; behavior

\begin{abstract}
ABSTRAK
Latar Belakang: Seks pranikah merupakan masalah yang rentan terjadi pada remaja. Salah satu penyebabnya adalah kurangnya pengetahuan tentang kesehatan reproduksi. Pendidikan kesehatan reproduksi sangat penting, tetapi mayoritas orangtua memiliki pengetahuan kurang serta persepsi negatif terhadap kesehatan reproduksi remaja.

Tujuan: Menganalisis perbedaan pengetahuan, sikap dan perilaku orangtua sebelum dan setelah diberikan intervensi Sapa Orangtua Remaja.

Metode: Rancangan penelitian quasi experimental non randomized pre test and post test one group design. Subjek penelitian ini adalah 35 orangtua siswa Sekolah Dasar Pamitran Kota Cirebon dengan kriteria inklusi dan eksklusi. Instrumen penelitian meliputi kuesioner dan modul Sapa Orang Tua Remaja. Analisis data menggunakan uji wilcoxon dan paired $t$-test.
\end{abstract}

Hasil dan Pembahasan: Terdapat perbedaan yang bermakna pengetahuan sikap dan perilaku orang tua sebelum dan setelah intervensi ( $p$ value 0,003; 0,000 dan 0,013).

Kesimpulan: Sapa orangtua remaja dapat meningkatkan pengetahuan, sikap dan perilaku orangtua tentang kesehatan reproduksi remaja.

Kata kunci: Sapa orangtua remaja; pengetahuan; sikap; perilaku 


\section{PENDAHULUAN}

Batasan usia remaja berdasarkan WHO adalah 1019 tahun. Di Indonesia, jumlah remaja usia tersebut diperkirakan sekitar 18\%. Remaja merupakan kelompok umur yang berada dalam masa peralihan dan rentan terhadap berbagai faktor eksternal dan internal yang berakibat perilaku negatif dan tidak sehat baik secara fisik, mental maupun sosial. ${ }^{1}$ Remaja sangat berisiko terhadap masalah kesehatan reproduksi yaitu perilaku seksual pranikah, NAPZA dan HIV AIDS. Seks pranikah merupakan masalah yang sangat rentan terjadi pada remaja. Sekitar $0,7 \%$ remaja perempuan dan $4,5 \%$ remaja laki-laki usia 15-19 tahun pernah melakukan seks pranikah. ${ }^{2}$

Faktor penyebab munculnya perilaku seksual adalah kurangnya pengetahuan tentang kesehatan reproduksi. Berdasarkan data Tahun 2013, hanya $35,3 \%$ remaja yang mengetahui bahwa perempuan dapat hamil dengan satu kali berhubungan seksual. ${ }^{3}$ Selain itu penyebab lain dari perilaku seksual berisiko adalah kurangnya komunikasi antara orangtua dan anak. $^{4}$

Selama ini, program Kementerian Kesehatan dalam memberikan informasi tentang kesehatan reproduksi melalui Pelayanan Kesehatan Peduli Remaja (PKPR) hanya diberikan pada siswa SMP dan SMU. Siswa SD sama sekali belum terpapar dengan pengetahuan tentang kesehatan reproduksi, padahal seperti yang telah disebutkan sebelumnya bahwa batasan usia remaja menurut WHO dimulai dari 10 tahun. Sebagian berpendapat, pendidikan kespro hanya bisa diberikan untuk siswa SMP dan SMU, sebab ada kekhawatiran siswa SD belum siap menerima. Padahal, dengan perkembangan teknologi yang semakin berkembang, maka siswa SD pun cenderung ingin tahu segala sesuatu yang berkaitan dengan seks, karena mereka sudah memasuki usia pubertas. ${ }^{5}$

Berdasarkan penelitian Kurniasari tahun 2010, terdapat hubungan antara umur dimulainya komunikasi tentang kesehatan reproduksi dengan perilaku seksual remaja. Prevalensi remaja yang berperilaku seksual yang berisiko 2,6 kali lebih banyak terjadi pada remaja yang mulai menjalin komunikasi tentang kesehatan reproduksi dengan orang tua pada umur yang terlambat (>12 tahun) dibandingkan dengan kelompok remaja yang mulai berkomunikasi seksual dengan orang tua pada umur lebih awal ( $\leq 12$ tahun). ${ }^{4}$

Pada tahun 2015 peneliti telah melakukan pengabdian masyarakat di salah satu SD di Kota Cirebon dengan memberikan pendidikan kesehatan reproduksi pada siswa SD usia 10-12 tahun sebanyak masing-masing 40 orang siswa ${ }^{6}$ dan pada tahun 2016 peneliti pun telah melakukan penelitian di Kabupaten Kuningan terhadap 80 orang siswa dengan memberikan pendidikan kesehatan reproduksi pada siswa SD usia 10-12 tahun. ${ }^{7}$ Berdasarkan hasil penelitian dan pengabdian masyarakat tersebut, siswa siswi SD yang sudah memasuki usia remaja (usia 10-12 tahun) sebenarnya sudah siap, bahkan sudah memerlukan pendidikan kesehatan reproduksi, karena mereka telah mengalami pubertas.

Pemberian pendidikan kesehatan reproduksi pada remaja sangat penting, akan tetapi hal ini masih dianggap tabu oleh orangtua. Remaja lebih senang untuk berdiskusi dengan temannya. Hal ini terbukti dari hasil SDKI Tahun 2012 tentang Kespro remaja yang menunjukkan lebih dari setengah wanita membicarakan menstruasi pertama dengan teman $(53,6 \%)$, bukan dengan ibunya. Selain itu, hanya $1,7 \%$ remaja pria membicarakan mimpi basah yang pertama dengan ibu, 1,4\% dengan ayah, sedangkan dengan teman sebanyak $48 \%{ }^{2}$

Berdasarkan penelitian Penelitian Joyo tahun 2016 tentang gambaran persepsi orang tua terhadap pendidikan seks pada anak usia sekolah di SDN 2 Banjarsari, Kabupaten Magelang terhadap 131 orang tua, mayoritas orangtua memiliki persepsi negatif sebesar $51.1 \%$ terhadap pendidikan seks. ${ }^{8}$ Penelitian lain menujukan pengetahuan orangtua tentang kesehatan reproduksi masih kurang dan sebagian orangtua memiliki sikap unfavourable terhadap pendidikan seksual yang dipengaruhi oleh adanya perasaan tabu dan canggung dalam berkomunikasi tentang topik pendidikan seksual. ${ }^{9}$

Pemberian pendidikan kesehatan reproduksi yang diberikan oleh orangtua sangatlah penting. Hasil penelitian Kartikasari dkk, intervensi pendidikan kesehatan pada keluarga berpengaruh terhadap pengetahuan orangtua. ${ }^{10}$ Berdasarkan penelitian Anugraheni, ada hubungan antara pengetahuan dan sikap orang tua terhadap pendidikan seks dengan tindakan orang tua dalam 
pemberian pendidikan seks pada remaja. ${ }^{11}$ Selain itu, Intervensi dengan melibatkan orangtua mampu meningkatkan kemampuan komunikasi orangtua dengan anak tentang seksualitas, meningkatkan pengetahuan dan sikap seksualitas terhadap remaja dan mencegah perilaku seks bebas pada remaja. ${ }^{12}$

Hasil survey pendahuluan di Puskesmas Pamitran Kota Cirebon, pada tahun 2017 terdapat 3 remaja yang hamil di luar nikah. Setelah melakukan wawancara terhadap 5 orangtua kelas 5 SD Pamitran, mayoritas orangtua belum tahu dan merasa tabu untuk membicarakan tentang kesehatan reproduksi pada anaknya. Selain survey pendahuluan, peneliti juga melakukan penelitian pendahuluan yang dilaksanakan di SD Pamitran pada bulan September 2018 dengan jumlah responden 40 ibu yang memiliki anak usia 10 sampai dengan 12 tahun. Berdasarkan hasil penelitian diperoleh sebagian besar orang tua $(51,8 \%)$ memiliki persepsi negatif terhadap pendidikan kespro pada siswa SD. Akan tetapi hal ini berbanding terbalik dengan hasil wawancara mendalam yang dilakukan kepada guru mengenai pendidikan kespro pada siswa SD, para guru memiliki persepsi yang positif dan mendukung pentingnya pemberian pendidikan kespro pada siswa SD. ${ }^{13}$ Berdasarkan latar belakang di atas, maka perlu dilakukan penelitian pengaruh intervensi Sapa Orangtua Remaja terhadap peningkatan pengetahuan, sikap dan perilaku orangtua.

\section{METODE}

Rancangan penelitian quasi experimental non randomized pre test and post test. Penelitian ini menganalisis perbedaan pengetahuan, sikap dan perilaku ibu setelah pemberian intervensi "Sapa Orangtua Remaja (Saroja)“. Penelitian dilakukan di wilayah kerja Puskesmas Pamitran, yaitu di SD Negeri Pamitran Kota Cirebon pada bulan Mei sampai dengan November 2018.

Populasi dalam penelitian ini adalah seluruh orangtua siswa SD usia 10-12 tahun di Kota Cirebon. Teknik pengambilan sampel dalam penelitian ini yaitu purposive sample yaitu orangtua siswa SD Pamitran yang berusia 10-12 tahun dengan jumlah sampel 35 orang. Kriteria inklusi yaitu orangtua yang menjadi responden adalah ibu yang memiliki anak usia 10-12 tahun di SD Pamitran pada Tahun 2018, bisa melihat dan bisa mendengar. Kriteria eksklusi yaitu tidak mengikuti pre test, tidak mengikuti seluruh intervensi atau tidak mengikuti post test. Penelitian ini menggunakan data primer. Pengumpulan data dibantu oleh enumerator yaitu 2 orang mahasiswi D.III Kebidanan Cirebon Poltekkes Kemenkes Tasikmalaya serta petugas UKS Puskesmas Pamitran. Instrumen penelitian menggunakan kuesioner serta modul Sapa Orangtua Remaja. Analisis yang digunakan adalah uji wilcoxon untuk variabel pengetahuan dan sikap dan paired t-test untuk variabel perilaku.

\section{HASIL DAN PEMBAHASAN}

Untuk variabel pengetahuan dan sikap, karena data tidak terdistribusi normal, maka menggunakan uji wilcoxon, sedangkan untuk variabel perilaku data terdistribusi normal, sehingga menggunakan paired t-test:

Tabel 1. Analisis Uji Wilcoxon Pengetahuan Orangtua Tentang Pendidikan Kesehatan Reproduksi Pada Siswa SD

\begin{tabular}{llrcr}
\hline & & N & Median (Min-Maks) & $\boldsymbol{p}$ \\
\hline Pengetahuan sebelum intervensi $(\mathrm{n}=35)$ & Negative Ranks & $3^{\mathrm{a}}$ & $39(36-40)$ & 0,003 \\
Pengetahuan setelah intervensi $(\mathrm{n}=35)$ & Positive Ranks & $15^{\mathrm{b}}$ & $40(38-40)$ & \\
& Ties & $17^{\mathrm{c}}$ & & \\
\hline & Total & 35 & \\
\hline
\end{tabular}

Berdasarkan uji wilcoxon pada tabel 1 diperoleh nilai $p$ value $0,003(<0,05)$, sehingga secara statistik terdapat perbedaan yang bermakna pengetahuan orang tua tentang pendidikan kesehatan reproduksi sebelum dan setelah intervensi. Responden dengan skor pengetahuan yang turun sebanyak 3 orang, meningkat 15 orang dan tetap 17 orang. 
Tabel 2. Hasil analisis uji wilcoxon sikap orangtua tentang pendidikan kesehatan reproduksi pada siswa SD

\begin{tabular}{llrcc}
\hline & & N & Median (Min-Maks) & $\boldsymbol{p}$ \\
\hline Sikap sebelum intervensi $(\mathrm{n}=35)$ & Negative Ranks & $2^{\mathrm{a}}$ & $65(53-72)$ & 0,000 \\
Sikap setelah intervensi $(\mathrm{n}=35)$ & Positive Ranks & $24^{\mathrm{b}}$ & $72(55-72)$ & \\
& Ties & $9^{\mathrm{c}}$ & & \\
\hline & Total & 35 & & \\
\hline
\end{tabular}

Berdasarkan uji wilcoxon pada tabel 2 diperoleh nilai $p$ value $0,000(<0,05)$, sehingga secara statistik terdapat perbedaan yang bermakna sikap orang tua tentang pendidikan kesehatan reproduksi sebelum dan setelah intervensi. Responden dengan skor sikap yang turun sebanyak 2 orang, meningkat 24 orang dan tetap 9 orang.

Tabel 3. Hasil Analisis Paired T-Test Perilaku Orangtua Tentang Pendidikan Kesehatan Reproduksi Pada Siswa SD

\begin{tabular}{cccc}
\hline Pre test Rata-rata (SD) & Post test Rata-rata (SD) & Beda rata-rata (CI 95\%) & $\boldsymbol{p}$ \\
\hline 4,54 & 5,29 & 0,743 & 0,013 \\
$(1,59)$ & $(0,86)$ & $(-1,32$ s.d $-0,16)$ & \\
\hline
\end{tabular}

Berdasarkan analisis statistik, diperoleh nilai $p$ value 0,013 , maka terdapat perbedaan yang bermakna rata-rata perilaku orangtua tentang pendidikan kesehatan reproduksi sebelum dan setelah intervensi.

Berdasarkan hasil analisis yang dilakukan menggunakan uji wilcoxon pada tabel 1 diperoleh $p$ value 0,003 , maka terdapat perbedaan pengetahuan orang tua tentang pendidikan kesehatan reproduksi sebelum dan setelah intervensi. Hasil penelitian ini sesuai dengan hasil penelitian Kartikasari dkk, yang menyatakan bahwa intervensi pendidikan kesehatan pada keluarga berpengaruh terhadap pengetahuan orangtua. ${ }^{10}$

Pengetahuan yang diukur pada penelitian ini adalah meliputi pentingnya pendidikan kesehatan reproduksi remaja yang meliputi tugas dan tanggung jawab keluarga, perubahan fisik dan psikologis pada remaja serta pengenalan sistem dan fungsi alat reproduksi, proses reproduksi yang dimulai dengan adanya tanda seks primer (menstruasi bagi perempuan dan mimpi basah bagi laki-laki) serta cara memelihara organ reproduksi, pergaulan yang sehat antara remaja laki-laki dan perempuan dan pendewasaan usia perkawinan, dampak dari pergaulan bebas yang meliputi kehamilan tidak diinginkan, aborsi, penyakit menular seksual, dan HIV/AIDS, bahaya narkoba dan miras, serta gizi seimbang bagi remaja.
Berdasarkan hasil penelitian pendahuluan terhadap orangtua siswa yang berusia 10-12 tahun di SD Pamitran diperoleh hasil, sebagian besar orang tua (51,8\%) memiliki persepsi negatif terhadap pendidikan kespro pada siswa SD. Menurut asumsi peneliti, persepsi negatif tersebut disebabkan karena pengetahuan orangtua tentang pendidikan kesehatan reproduksi masih kurang. Batasan usia untuk remaja awal menurut WHO adalah usia 1014 tahun, sehingga siswa SD dengan usia 10-12 tahun sudah memasuki masa remaja. Akan tetapi, mayoritas orang tua bahkan banyak orang tidak menyadari, jika siswa SD dengan usia 10-12 tahun sudah memasuki masa remaja, hal ini terjadi karena kurangnya informasi mengenai hal tersebut. Hal ini terbukti dari nilai median (minimun-maksimum) pengetahuan orangtua sebelum diberikan intervensi pendidikan kesehatan reproduksi dalam bentuk "Sapa orangtua remaja (SAROJA)" sebesar 39 (36-40), sedangkan setelah intervensi nilai median (minimun-maksimum) menjadi 40 (38-40). Artinya intervensi yang diberikan memberikan hasil yang signifikan terhadap peningkatan pengetahuan orangtua terhadap kesehatan reproduksi remaja.

Jika memiliki pengetahuan yang baik, orangtua diharapkan dapat memiliki sikap dan tindakan dalam memberikan pendidikan kesehatan reproduksi kepada anaknya, sehingga dapat mencegah perilaku seksual berisiko. Hal ini sesuai 
dengan penelitian Anugraheni, yang menyatakan ada hubungan antara pengetahuan dan sikap orang tua terhadap pendidikan seks dengan tindakan orang tua dalam pemberian pendidikan seks pada remaja. ${ }^{11}$ Selain itu, intervensi dengan melibatkan orangtua mampu meningkatkan kemampuan komunikasi orangtua dengan anak tentang seksualitas, meningkatkan pengetahuan dan sikap seksualitas terhadap remaja dan mencegah perilaku seks bebas pada remaja. ${ }^{12}$

Sikap orangtua sebelum diberikan intervensi Sapa orangtua remaja memiliki nilai median (minimum-maksimum) 65 (53-72) jika dibandingkan dengan median (minimum-maksimum) setelah pemberian intervensi yaitu 72 (55-72). Artinya intervensi yang diberikan memberikan hasil yang signifikan terhadap peningkatan sikap orangtua terhadap kesehatan reproduksi remaja.

Nilai median yang rendah sebelum pemberian intervensi sesuai dengan penelitian yang menunjukan sikap orangtua tentang kesehatan reproduksi masih kurang dan sebagian orangtua memiliki sikap unfavourable terhadap pendidikan seksual yang dipengaruhi oleh adanya perasaan tabu dan canggung dalam berkomunikasi tentang topik pendidikan seksual. Peran keluarga dalam kesehatan dan reproduksi bagi remaja dibutuhkan untuk mengatur dan mengendalikan perilaku seksual remaja yang rawan mengalami penyimpangan. ${ }^{9}$

Berdasarkan uji wilcoxon pada tabel 2 diperoleh nilai $p$ value $0,000(<0,05)$, sehingga secara statistik terdapat perbedaan yang bermakna sikap orang tua tentang pendidikan kesehatan reproduksi sebelum dan setelah intervensi. Hasil penelitian ini sesuai dengan penelitian Wight, $\mathrm{Ph}$ \& Fullerton, yang menyatakan intervensi dengan melibatkan orangtua mampu meningkatkan kemampuan komunikasi orangtua dengan anak tentang seksualitas, sehingga meningkatkan pengetahuan dan sikap seksualitas terhadap remaja dan mencegah perilaku seks bebas pada remaja. ${ }^{12}$

Perilaku orangtua tentang pendidikan kesehatan reproduksi pada penelitian ini meliputi, pemberian informasi tentang menstruasi atau mimpi basah, perubahan fisik yang terjadi pada remaja, dampak hubungan seksual sebelum menikah meliputi kehamilan tidak diinginkan, dan penyakit menular seksual, termasuk HIV/AIDS, dampak penyalahgunaan narkoba dan gizi seimbang.

Berdasarkan analisis statistik pada tabel 5 , diperoleh nilai $p$ value 0,013 , maka terdapat perbedaan yang bermakna rata-rata perilaku orangtua tentang pendidikan kesehatan reproduksi sebelum dan setelah intervensi. Rata-rata perilaku orangtua sebelum intervensi sebesar 4,54 dan setelah intervensi sebesar 5,29. Hasil penelitian ini sesuai dengan penelitian yang menyatakan intervensi dengan melibatkan orangtua mampu meningkatkan kemampuan komunikasi orangtua dengan anak tentang seksualitas dan mencegah perilaku seks bebas pada remaja). ${ }^{12}$

Perilaku merupakan refleksi dari berbagai gejala kejiwaan seperti keinginan minat kehendak pengetahuan emosi, berfikir, sikap, motivasi, reaksi dan sebagainya. Namun demikian sulit dibedakan refleksi dari gejala kejiwaan seseorang. Perilaku dibedakan menjadi tiga bentuk perilaku membedakan menjadi tiga bentuk perilaku yaitu kognitif, afektif dan psikomotor. Pendapat lain menyebutkan bahwa perilaku terdiri dari knowledge (pengetahuan), attitude (sikap), practice (tindakan). Sedangkan dalam pengertian umum perilaku adalah segala perbuatan atau tindakan yang di lakukan oleh mahluk hidup.

Bila remaja tidak mendapatkan pemahaman yang lengkap tentang kesehatan reproduksi dari orangtua, maka remaja rentan terhadap sumbersumber informasi dari luar yang salah tentang seksualitas. ${ }^{14} \mathrm{Jika}$ orangtua memberikan pendidikan kesehatan reproduksi, diharapkan dapat mencegah perilaku seksual yang berisiko pada remaja.

\section{KESIMPULAN DAN SARAN}

Terdapat perbedaan yang bermakna pengetahuan, sikap dan perilaku orangtua tentang pendidikan kesehatan reproduksi sebelum dan setelah intervensi, sehingga Sapa orangtua remaja hendaknya menjadi pertimbangan program kegiatan bagi Dinas Kesehatan Kota Cirebon di dalam meningkatkan pengetahuan, sikap dan perilaku orangtua tentang pendidikan kesehatan reproduksi remaja, khususnya pada orangtua siswa SD usia 1012 tahun. 


\section{DAFTAR PUSTAKA}

1. Kemendikbud, Kemenkes RI, Kemenag, UNFPA, Unesco. Modul Pendidikan Kesehatan Reproduksi Untuk Peserta Didik SD/MI dan sederajat (Pegangan Bagi Guru). Indonesia; 2014.

2. Badan Pusat Statistik, Kementerian Kesehatan RI, MEASURE DHS, ICF Intervnational. Survei Demografi dan Kesehatan Indonesia Kesehatan Reproduksi Remaja. 2013.

3. Pusat Data dan Informasi Kementerian Kesehatan RI. Situasi Kesehatan Reproduksi Remaja. Jakarta; 2014.

4. Kurniasari D. Komunikasi Orang Tua Dan Perilaku Seksual Remaja Sekolah Menengah Kejuruan Di Kota Baturaja. Universitas Gadjah Mada; 2010.

5. Pertiwi KR. Urgensi Pendidikan Kesehatan Reproduksi Sebagai Bagian Intergratif Pembelajaran IPA. Universitas Negeri Yogyakarta; 2007.

6. Nurcahyani L, Widiyastuti D, Jubaedah E, Nurasih. Sapa Remaja Sebagai Upaya Peningkatan Pengetahuan Remaja Tentang Kesehatan Reproduksi Pada Remaja di Wilayah Puskesmas Pamitran Kota Cirebon Tahun 2015. 2015.

7. Nurcahyani L, Widiyastuti D, Jaenudin, Maryani $H$. Reproductive Health Education With Pupuh Sunda Among Elementary Students In Kuningan District Of West Java. 2017;23-6.

8. Joyo TSB. Gambaran Persepsi Ortu terhadap Pendidikan Seks pada Anak Usia Sekolah di SDN 2 Banjarsari Kecamatan Windusari Kabupaten MAgelang. Universitas Diponogoro; 2016.
9. Sholihatina A, Mardhiyah A, Simangunsong B. Pengetahuan dan Sikap Orang Tua terhadap Pendidikan Seksual Remaja Autis pada Fase Pubertas di SLBN Cibiru dab SLB Pelita Hafidz Bandung. Students e J. 2012;1(1):1-16.

10. Kartikasari A, Subronto YW, Madyaningrum E. Pengaruh Intervensi Pendidikan Kesehatan pada Keluarga terhadap Pengetahuan dan Sikap Orangtua tentang Pendidikan Seksual dan Reproduksi Remaja. Universitas Gadjah Mada; 2015.

11. Anugraheni E. Hubungan Pengetahuan dan Sikap Orangtua Tentang Pendidikan Seks dengan Tindakan Orangtua dalam Pemberian Pendidikan Seks Pada Remaja. Universitas Jember; 2013.

12. Wight D, Ph D, Fullerton D. A Review of Interventions With Parents to Promote the Sexual Health of Their Children. J or Adolesc Heal [Internet]. 2013;52(1):427. Available from: http://dx.doi.org/10.1016/j. jadohealth.2012.04.014

13. Nurcahyani L, Widiyastuti D. Perspsi orangtua dan guru terhadap pendidikan kesehatan reproduksi pada siswa SD di Kota Cirebon. Poltekkes Kemenkes Tasikmalaya; 2018.

14. Uyun Z. Peran Orangtua Dalam Pendidikan Kesehatan Reproduksi. Pros Semin Nas Parent 2013. 2013;35672. 